\title{
Magdalena Grabowska, Komunikacja oknem na kulturę. Wspólnota dyskursu kulturowym wymiarem funkcjonowania spoleczności ewangelikalnej, Wydawnictwo Uniwersytetu Gdańskiego, Gdańsk 2017, ss. 235
}

W książce Komunikacja oknem na kulturę. Wspólnota dyskursu kulturowym wymiarem funkcjonowania społeczności ewangelikalnej Magdalena Grabowska skupia się na analizie zachowań komunikacyjnych charakterystycznych dla protestantów ewangelikalnych. Za cel stawia sobie rekonstrukcję obrazu ich tożsamości oraz opis kultury tej grupy. Zdaniem badaczki najbardziej widoczną podstawę wspólnotowości członków grup o charakterze ewangelikalnym stanowi dyskurs. Wiele uwagi w pracy autorka poświęca więc zjawisku tzw. ewangelikalnej mowy obecnej w gatunkach najczęściej występujących w komunikacji ewangelikalnej: kazaniach, świadectwach i modlitwach.

Znaczną część opracowania Grabowska przeznacza na przedstawienie problemów teoretycznych związanych z tematyką pracy. Na początku rozważań umieszczono uwagi o charakterze językoznawczym (s. 17-88). Co istotne, przytaczając każdy ze sposobów ujmowania języka i komunikacji, autorka uwypukla stanowiącą przedmiot pracy kwestię związku języka używanego przez daną społeczność z jej kulturą. Ponadto wszystkie poruszone problemy są ważne dla analizy materiału badawczego. Następnie badaczka prezentuje podstawowe informacje na temat ewangelikalizmu (s. 89-111). Definiuje go jako nurt ponadwyznaniowy w protestantyzmie, nurt, w którym podkreśla się m.in. konieczność nawrócenia (rozumianego jako wydarzenie jednorazowe stanowiące swoisty przełom w biografii człowieka). Pozostałymi wyznacznikami ewangelikalizmu są: konieczność uświęcania się oraz prowadzenia działalności ewangelizacyjnej, biblizm, a także - krzyżocentryzm. Do kierunku ewangelikalnego w Polsce Grabowska zalicza wspólnoty baptystyczne i charyzmatyczno-zielonoświątkowe. Badaczka przedstawia dynamikę rozwoju tego nurtu oraz zmianę dominujących w nim tendencji na przestrzeni lat: w Europie 
Zachodniej, w Stanach Zjednoczonych, a także - w Polsce. Prezentuje również jego charakterystyczne cechy zauważalne obecnie na gruncie polskim. Ponadto w pracy omówiono podobieństwa i różnice między odłamem baptystycznym i zielonoświątkowym. Zwrócono też uwagę na specyfikę nurtu neozielonoświątkowego. Ten wyczerpujący opis stanowi ważne wprowadzenie do refleksji na temat języka i kultury protestantów ewangelikalnych.

Omówiony w pracy materiał językowy zebrano ze stron internetowych oraz w toku obserwacji uczestniczącej (s. 113-117). Autorka deklaruje, iż pragnęła zbadać dyskurs zarówno ludzi wiążących swoją tożsamość z ewangelikalnym chrześcijaństwem, jak i tych, którzy dopiero zaczynają się identyfikować z tym nurtem. Badaczka prowadziła obserwację nabożeństw i sytuacji poza nimi we wspólnocie, do której należy, a także nawiązała kontakt z innymi chrześcijanami z interesującego ją nurtu. Deklaruje, że udało jej się poznać ich poglądy na sprawy wiary. Ze stron internetowych Grabowska pozyskała nagrania nabożeństw, kazań i modlitw z różnych Kościołów ewangelikalnych w Polsce. Autorka nie precyzuje jednakże, czy wszystkie te nagrania miały charakter audialno-wizualny, czy też niektóre z nich były przeznaczone wyłącznie do odsłuchiwania. Nie określa również, z iloma osobami miała do czynienia, nie podaje nazw wspólnot, z których wywodzili się jej rozmówcy, ani nie precyzuje, z jakiej liczby nagrań korzystała i - co motywuje kwestiami etycznymi z których stron internetowych te nagrania pochodziły. Informuje jedynie, kiedy prowadziła obserwacje i w jakim okresie powstały nagrania. Również opis przebiegu badań wydaje się mało precyzyjny. Grabowska wspomina na przykład, iż z pewnym małżeństwem reprezentującym nurt charyzmatyczny przez wiele lat rozmawiała na tematy związane $\mathrm{z}$ wiarą.

Na początku analizy materiału językowego autorka określa, iż pragnie przedstawić komunikację ewangelikalną z punktu widzenia aktów mowy, zwracając uwagę na temat wypowiedzi, jej funkcję, typowe środki językowe służące do realizacji zamiarów komunikacyjnych, a także - na jej adresata (s. 120-135). Badaczka nie różnicuje jednak wypowiedzi pod względem gatunkowym - nie zaznacza, czy pochodzą one ze świadectw, z kazań, z modlitw, czy też - ze swobodnych rozmów przeprowadzanych w badanym środowisku. Wydaje się, że to dość poważne zaniedbanie, gdyż wymienione gatunki znacznie różnią się między sobą, a ewangelikalna modlitwa, jak przyznaje sama autorka, charakteryzuje się sporym zróżnicowaniem wewnętrznym. Mimo że badaczka deklaruje, iż przedmiot analizy stanowią wypowiedzi, po przywołaniu połączeń wyrazowych charakterystycznych dla danego tematu nie zawsze cytuje wypowiedzi, w których one wystąpiły. Brak również informacji, z jakiego źródła pochodzi dany cytat, co z kolei stanowi brak precyzji w uję- 
ciu zagadnienia. Kolejną usterkę analizy stanowi to, iż jedynie w niektórych wypadkach badaczka zamieszcza definicje zaprezentowanych sformułowań. Dość szczegółowo opisuje natomiast rozmaite działania językowe związane z danym tematem, używając formuł: mówię, że... bądź mówię o..., co można uznać za walor pracy (s. 122-135).

Następny etap rozważań stanowi ukazanie poszczególnych gatunków reprezentatywnych dla mowy ewangelikalnej (s. 136-163). Nietrudno zauważyć, iż w wypadku każdego z omawianych gatunków materiał badawczy jest zbyt skąpy, by kompleksowo opisać zagadnienie. W pierwszej kolejności autorka porównuje bowiem trzy kazania wygłoszone w Kościołach: baptystycznym, charyzmatycznym i zielonoświątkowym (s. 136). W dalszej części pracy analizie zostały poddane dwa tzw. świadectwa. Nie zaznaczono jednak, z których nurtów ewangelikalizmu pochodzą (s. 145-146). W części poświęconej modlitwie badaczka przygląda się trzem wypowiedziom z nurtów: neocharyzmatycznego, zielonoświątkowego i baptystycznego (s. 153).

Należałoby także podać w wątpliwość to, czy analizowane wypowiedzi są względem siebie ekwiwalentne, a co za tym idzie - czy można precyzyjnie porównać użyte w nich środki językowe. Przytoczone kazania znacznie różnią się bowiem pod względem tematycznym (s. 137). Zestawianie analizowanych w pracy świadectw budzi z kolei wątpliwości ze względu na kategorię odbiorcy. Jedno z nich zostało wypowiedziane przed ludźmi w zborze, drugieprzed osobami spoza wspólnoty (s. 145-146). Wydaje się, że zasadne byłoby porównywanie środków językowych użytych w owych świadectwach, o ile ich nadawcy pochodziliby z wspólnot tego samego typu. Należałoby także zestawić świadectwa kierowane do jednakowego rodzaju odbiorcy, wygłoszone jednak przez wiernych ze wspólnot reprezentujących odmienne nurty ewangelikalizmu. Analizowane w pracy modlitwy znacznie różnią się pod względem długości: pierwsza stanowi 6-minutowy monolog, druga-45-minutową modlitwę równoczesną, trzecia z kolei to również modlitwa zbiorowa, tym razem - konwersacyjna, o której długości badaczka nie informuje (s. 153, 158, 159). Wydaje się, że należałoby tu więcej uwagi poświęcić kwestii zasadności porównywania wspomnianych form modlitwy. Modlitwa równoczesna jest typową formą dla nurtu charyzmatyczno-zielonoświątkowego, natomiast modlitwa konwersacyjna - dla baptystycznego, dlatego też porównanie ich jako form modlitwy zbiorowej może w pewnym wymiarze okazać się zasadne. Miarodajne wydaje się również zestawienie monologu z modlitwą konwersacyjną. Modlący się przedstawiciel wspólnoty protestanckiej, niezależnie od tego, czy modli się sam, czy też z innymi, wierzy bowiem, że to Duch Święty kieruje jego modlitwą [Bogacz 2019: 135]. Prawdopodobnie używa 
więc takich samych środków językowych, stosując monolog, co modląc się $\mathrm{w}$ dialogu $\mathrm{z}$ innymi. $\mathrm{W}$ pracy nie udzielono jednak odpowiedzi na pytanie, czy w modlitwie równoczesnej, ze względu na jej silnie emocjonalny charakter, wierni stosują nieco inne środki językowe niż w modlitwie monologowej czy konwersacyjnej. Badaczka nie rozstrzyga też problemu związanego z tym, czy kiedy na forum wypowiada się jedna osoba, staranniej dobiera środki językowe niż ktoś, kogo głos niknie w tłumie.

Niezmiernie cenne jest to, że w pracy dokładnie opisano szeroki kontekst omawianych wypowiedzi. Nie tylko zatem uwzględniono warunki ich powstawania, lecz także scharakteryzowano je na tle owych gatunków w dyskursie katolików. Umożliwiło to ukazanie ogólnej dynamiki rozwoju dyskursu religijnego i unikatowości dyskursu badanej grupy.

Niewątpliwie mocną stroną wywodu jest próba uchwycenia związku między doktrynami branych pod uwagę Kościołów i formą wypowiadanych w nich kazań czy modlitw. Wskazuje to na wewnętrzne zróżnicowanie ewangelikalizmu oraz na to, w jaki sposób kultura danej społeczności odbija się w używanym przez ową grupę dyskursie.

Za słuszne można uznać to, że badaczka nie nazywa ewangelikalnej mowy żargonem, ale jedynie zauważa w niej pewne jego elementy (s. 140). Nie zawsze bowiem przejawia się tu potoczność. Niemniej nie wiadomo, dlaczego w trakcie analizy uczona za żargonowe uznaje słowo zborownicy (s. 140) czy sformułowanie pragnienie w sercu (s. 148).

Poważną wadą opracowania materiału badawczego jest brak informacji o częstotliwości występowania charakterystycznych, zdaniem autorki, cech języka protestantów ewangelikalnych. W niektórych przypadkach zaznacza jedynie, że są one częste bądź też - nieliczne (por. s. 169). Trudno jednak stwierdzić, na jakiej podstawie o tym orzeka.

Za niewątpliwy walor pracy można uznać poświęcenie jednego z rozdziałów osobliwościom mowy zielonoświątkowo-charyzmatycznej (s. 165-173), różniącej się przecież od mowy chrześcijan baptystów. Badaczka nie ukazuje jednak złożoności środowiska zielonoświątkowo-charyzmatycznego i pomija to, że formuły językowe pojawiające się w społecznościach o charakterze konserwatywnym w dużym stopniu różnią się od tych stosowanych w grupach związanych z tzw. trzecią falą [Bogacz 2019: 69-71].

Ważny element wywodu stanowi próba wskazania tendencji obecnych w ewangelikalnej mowie (s. 173-178). Autorka publikacji przedstawia tu refleksje wysnute na podstawie analizy ponad 500 formuł językowych występujących w środowiskach ewangelikalnych. Tej części rozważań można zarzucić brak konsekwencji, gdyż badaczka spory fragment analizy poświęca przy- 
taczaniu sformułowań użytych w kazaniu wygłoszonym w jednej ze wspólnot charyzmatycznych (s. 175), a także podaje przykłady słów pojawiających się w wypowiedziach konkretnego kaznodziei (s. 176). Niezwykle cenne jest jednak to, że Grabowska podejmuje próbę wskazania genezy omawianych sformułowań. Nie informuje jednak, jaka ich część prawdopodobnie wywodzi się z konkretnych źródeł. Co istotne, zaznaczono tu, w których nurtach ewangelikalizmu pojawiają się konkretne sformułowania.

Na początku rozdziału dotyczącego obrazu tożsamości protestantów ewangelikalnych (s. 179-194) Grabowska podkreśla, iż tożsamość w grupie społecznej kształtuje się na podstawie tego, jak owa grupa widzi siebie samą oraz w jaki sposób postrzegają ją Inni. Ważna jest wybrzmiewająca w pracy świadomość, że idzie tu o postrzeganie siebie na tle Innych - przedstawiając prawie wszystkie cechy tożsamości protestantów ewangelikalnych, autorka publikacji odwołuje się do realiów uniwersum katolickiego (por. s. 180-181). Co istotne, badaczka w opracowaniu nawiązuje do teorii językowego obrazu świata, a więc wydaje się, iż brakuje tutaj wprowadzenia pojęć auto- i heterostereotypu [Bartmiński, Panasiuk 2001: 387-388]. Ponadto w omawianej części pracy dogłębnie został scharakteryzowany sposób postrzegania siebie samych przez protestantów pentekostalnych, całkowicie zaś pominięto kwestię ich obrazu w oczach Innego. Autorka wyczerpująco opisuje natomiast tożsamość zewnętrzną (s. 181-185) i wewnętrzną (s. 186-194) badanej grupy.

W końcowej części pracy Grabowska stawia sobie za cel dokonanie charakterystyki kultury protestantów pentekostalnych na podstawie analizy ich zachowań komunikacyjnych (s. 195-207). Co istotne, bierze tu pod uwagę zarówno elementy językowe, jak i parajęzykowe. Część rozdziału stanowi omówienie kwestii oralnego charakteru tej komunikacji (s. 198-200). Niewątpliwą zaletą pracy jest to, że badaczka nie tylko podaje liczne argumenty świadczące o owej cesze, lecz również ujmuje specyfikę oralności w różnych nurtach ewangelikalizmu. Co niezwykle cenne, uczona dogłębnie wyjaśnia, na czym polega nieformularność i spontaniczność ewangelikalnej mowy, mimo występowania w niej licznych, omówionych wcześniej, formuł, pewnej struktury wypowiedzi i postępującej rytualizacji zachowań. Rozdział zamykają refleksje dotyczące obrazu Boga i chrześcijanina (s. 205-207). Poważnym brakiem jest tu jednak nieuwzględnienie różnic w konstruowaniu owego obrazu przez przedstawicieli różnych nurtów ewangelikalizmu [por. Bogacz 2019: 250-264].

Reasumując, problem podjęty przez Grabowską z pewnością jest istotny naukowo. Refleksja na temat dyskursu, a co za tym idzie - kultury protestantów ewangelikalnych umożliwia ukazanie kierunków rozwoju polskiej kultury religijnej. Środowiska ewangelikalne od kilkudziesięciu lat wywierają bowiem 
wpływ na ruch odnowy w Kościele katolickim [por. Migda 2013: 169-171]. Opisywanie dyskursu polskich protestantów ewangelikalnych jest tym bardziej istotne, iż do tej pory podjęli się tego nieliczni badacze [por. Bogacz 2019; Modnicka 2013; Pasek, Sorbjan 2017]. Dokładne opracowanie tematu wymagałoby jednak potwierdzania własnych intuicji w bogatszym materiale badawczym, większej dogłębności opisu owego materiału, a także - konsekwencji metodologicznej.

Karolina Bogacz-Kańka

\section{Bibliografia}

Bartmiński Jerzy, Panasiuk Jolanta (2001), Stereotypy językowe, w: Wspótczesny język polski, red. Jerzy Bartmiński, Lublin, s. 271-395.

Bogacz Karolina (2019), Obraz Boga i chrześcijanina utrwalony w dyskursie protestantów pentekostalnych, praca doktorska napisana w Katedrze Lingwistyki Kulturowej i Socjolingwistyki na Wydziale Polonistyki Uniwersytetu Jagiellońskiego pod kierunkiem prof. dr hab. Haliny Kurek, Kraków.

Migda Andrzej (2013), Mistycyzm pentekostalny w Polsce, Kraków.

Modnicka Noemi (2013), Małe światy polskiego ewangelikalizmu. Studium z antropologii interpretatywnej, Łódź.

Pasek Zbigniew, Sorbjan Bogusław (2017), Świadectwa wiary członków Kościoła Zielonoświątkowego jako forma perswazji religijnej, „Rocznik Teologiczny”, z. 1, s. $173-196$. 